\title{
Pesticide Contamination in Drinking and Surface Water in the Cienega, Jalisco, Mexico
}

\author{
Rosa J. Silva-Madera • Joel Salazar-Flores • A. Aarón Peregrina-Lucano • Judith \\ Mendoza-Michel • Hazael R. Ceja-Gálvez • Daniel Rojas-Bravo • Mireya Z. \\ Reyna-Villela $\cdot$ Erandis D. Torres-Sánchez $(\mathbb{D}$
}

Received: 23 September 2020 / Accepted: 4 January 2021 / Published online: 23 January 2021

(C) The Author(s) 2021

\begin{abstract}
Sixty percent of global agricultural production depends on the use of pesticides, despite their adverse effects on human health and the ecosystem. In Mexico, the application of these products has been exacerbated, including pesticides already banned in other countries. The objective of this study was to determine pesticide concentrations in samples of water purification plants and surface water from the Cienega area of Jalisco, Mexico. A survey of 119 farmers with occupational exposure to pesticides was carried out in order to obtain information on the most frequently used pesticides. Subsequently, 51 samples taken at 7 different sites were analyzed using liquid chromatography and mass-mass spectrometry. The most frequently used pesticides were organophosphates $(28.87 \%)$, pyrethroids
\end{abstract}

Rosa J. Silva-Madera and Joel Salazar-Flores contributed equally to this work.

R. J. Silva-Madera · J. Salazar-Flores • H. R. Ceja-Gálvez • E. D. Torres-Sánchez $(\bowtie)$

Department of Medical and Life Sciences. University Center of La Cienega, University of Guadalajara (CUCI-UdeG), Av. Universidad \# 1115, C.P. 47810 Ocotlán, Jalisco, Mexico e-mail: erandis.torres@academicos.udg.mx

\section{A. A. Peregrina-Lucano · J. Mendoza-Michel}

Department of Pharmacobiology, University Center of Exact Sciences and Engineering, University of Guadalajara, Blvd. Marcelino García Barragán 1421, esq Calzada Olímpica, Module E, 44430 Guadalajara, Jalisco, Mexico

D. Rojas-Bravo • M. Z. Reyna-Villela

Department of Technological Sciences. University Center of La Cienega, University of Guadalajara (CUCI-UdeG), Av.

Universidad \# 1115, C.P. 47810 Ocotlán, Jalisco, Mexico
(12.89\%), and the herbicide paraquat (31.95\%). In surface water, the prevalent pesticides were glyphosate (56.96-510.46 ppb) and malathion (311.76$863.49 \mathrm{ppb})$. Glyphosate levels were higher than the limits acceptable in daily water intake in Cumuato. Malathion levels exceeded the limits permissible by EPA in water purification plants in urban public establishments (100 ppb for children, and $200 \mathrm{ppb}$ for adults). In addition, a multidimensional scaling analysis showed that the sampled sites could be grouped into 2 different bodies of water, based on similarities in their glyphosate concentrations ( stress $=0.005$ ), while the concentrations of malathion were heterogeneous (stress $=0.001$ ).

Keywords Pesticides - Water purification plants . Surface water $\cdot$ HPLC-MS/MS $\cdot$ Cienega-Jalisco

\section{Introduction}

The Cienega area belongs to the states of Jalisco and Michoacán which cover an area of size $4892 \mathrm{~km}^{2}$, with an average annual rainfall of $809 \mathrm{~mm}$, and a semi-humid climate (CEA 2020). The Lerma-Santiago Basin and Chapala Lake are located in this region (CEA 2020). Previous evidence from the Lerma-Santiago River indicates high concentrations of fertilizers in the area (Ibarrarán et al. 2017; Pérez-Díaz et al. 2019). The water flowing from the Lerma and Zula rivers feeds the lake of Chapala (Camps and Arroyo 2018). The Zula River runs through $85.89 \%$ of the municipality of Ocotlán (a priority agricultural area) that feeds on the run-off, leading to a high level 
of fertilizers (CEA 2020; Sanchez et al. 2007). The tributary Palmar basin is nourished by the Chapala Lake, and it is a region popular for restaurant services (CEA 2020). On the other hand, Lerma river (section Cumuato) is located in the state of Michoacán, and it is a source of water supply to the agricultural areas of the community of Cumuato and its surroundings (INAFED 2020).

In 2015, it was reported that three-quarters of the water supply in the Cienega area was used for agricultural activities (CEA 2020). Thus, water supply in the Cienega area serves as its main economic engine (INAFED 2020). The application of pesticides has increased due to agricultural activities. A Jalisco-based study by Ortiz and collaborators (2013) reported increased frequencies in the use of organophosphates (19\%), pyrethroids (20\%), carbamates (14\%), bipyridyls (6\%), organochlorines (1\%), amongst others, in 2012 (Ortíz et al. 2013). Semarnat (2020) has been reported the use of 140 bioactive components of pesticides banned in other countries and CONAGUA indicated the increased use of pesticides has accentuated pollution of water sources in the region, as indicated for 28 points for Chapala Lake, and 22 points for the Lerma River (Semarnat 2020). Therefore, the objective of this study was to determine the concentrations of pesticides in water purification plants and surface waters in the Cienega region: Chapala lake, Zula river, Palmar tributary, Lerma river section Cumuato, community of Cumuato and Ocotlán, Jalisco, Mexico.

\section{Material and Methods}

This investigation was carried out as an exploratory and descriptive study. The determination of pesticides was done at the Laboratory of Applied Pharmacokinetics, University Center of Exact Sciences and Engineering (CUCEI) of the University of Guadalajara. Prior to sampling, a survey on the pesticides used and the frequencies of their applications in the region was conducted using 119 volunteer farmers. He wondered about the application season, which was at least twice a year, once when maize is grown (June to October) and the other when wheat is grown (January to May). On the other hand, questions were raised about the time of use of pesticides in the region, and the subjects indicate that they are used from about two decades to date. It should be mentioned that sampling from July to September was during the period of application of these pesticides (June-October).

\subsection{Sampling}

Fifty-one (51) water samples were taken from seven points: (a) Lake Chapala (5 samples), (b) River Zula (5 samples), (c) tributary Palmar (5 samples), (d) stretch of the Lerma Cumuato River (12 samples), (e) community Cumuato (5 samples), and the community of Ocotlán (19 samples) which is divided into: $(f) 11$ samples of water purification plants and $(g) 8$ samples from the University Center of La Ciénega, CUCI located in the border area where the crops start (Fig. 1). Samples taken from point $(a)$ to $(e)$ as well as $\operatorname{dot}(g)$ were surface water from tributaries, while those in item $(f)$ correspond to water purification plant samples.

\subsection{Processing}

The sampling was carried out in the rainy season which occurs in the region from July to September 2019, the period of the year during which the use of pesticides increases. Such sampling was carried out in a single series and at the same time for each sampled point, during the indicated period. Water samples $(50 \mathrm{~mL})$ from the middle part of the flows were collected in sterile polyethylene vessels and kept at $4{ }^{\circ} \mathrm{C}$ prior to until transfer to the laboratory where they were filtered with $0.2 \mu \mathrm{m}$ Whatman before injection to the chromatograph. On the other hand, $50 \mathrm{~mL}$ of water was taken from 11 purifying plants for human consumption following the same collection protocol as for surface water before injection to the chromatograph. The analysis of the samples was performed using multiple reactions at a flow rate of $0.5 \mathrm{~mL}$ per minute in an Agilent Technologies liquid chromatograph 1200 () coupled to mass spectrometry 6430B with a column C18 Zorbax Eclipse XDB of dimensions $50 \mathrm{~mm} \times 2.1 \mathrm{~mm} \times 3.5 \mu \mathrm{m}$. The mobile phases comprised $0.1 \%$ formic acid in water and a gradient of $40-100 \%$ acetonitrile at a flow rate of $0.5 \mathrm{~mL}$ per minute. The curve range for each pesticide was $0.01-1000 \mu \mathrm{g} / \mathrm{mL}$ (Schaner et al. 2007; Arora et al. 2007). Twenty-two pesticides were analyzed. The standards used (99\% purity) were as follows: parathion, picloram, ametrine, 2,4-dichlorophenoxyacetic acid (2,4-D), pyraclostrobin, malathion, diazinon, imazalil, dimethoate, carbofuran, atrazine, thiabendazole, molinate, acetachlor, carbendazin, Emamectin, cialotrin, meclizine, methomyl, methoxymers, oxandrolone, and glyphosate from AccuStandard ${ }^{\circledR}$. The electrospray interface conditions (EICs) were gas temperature of 


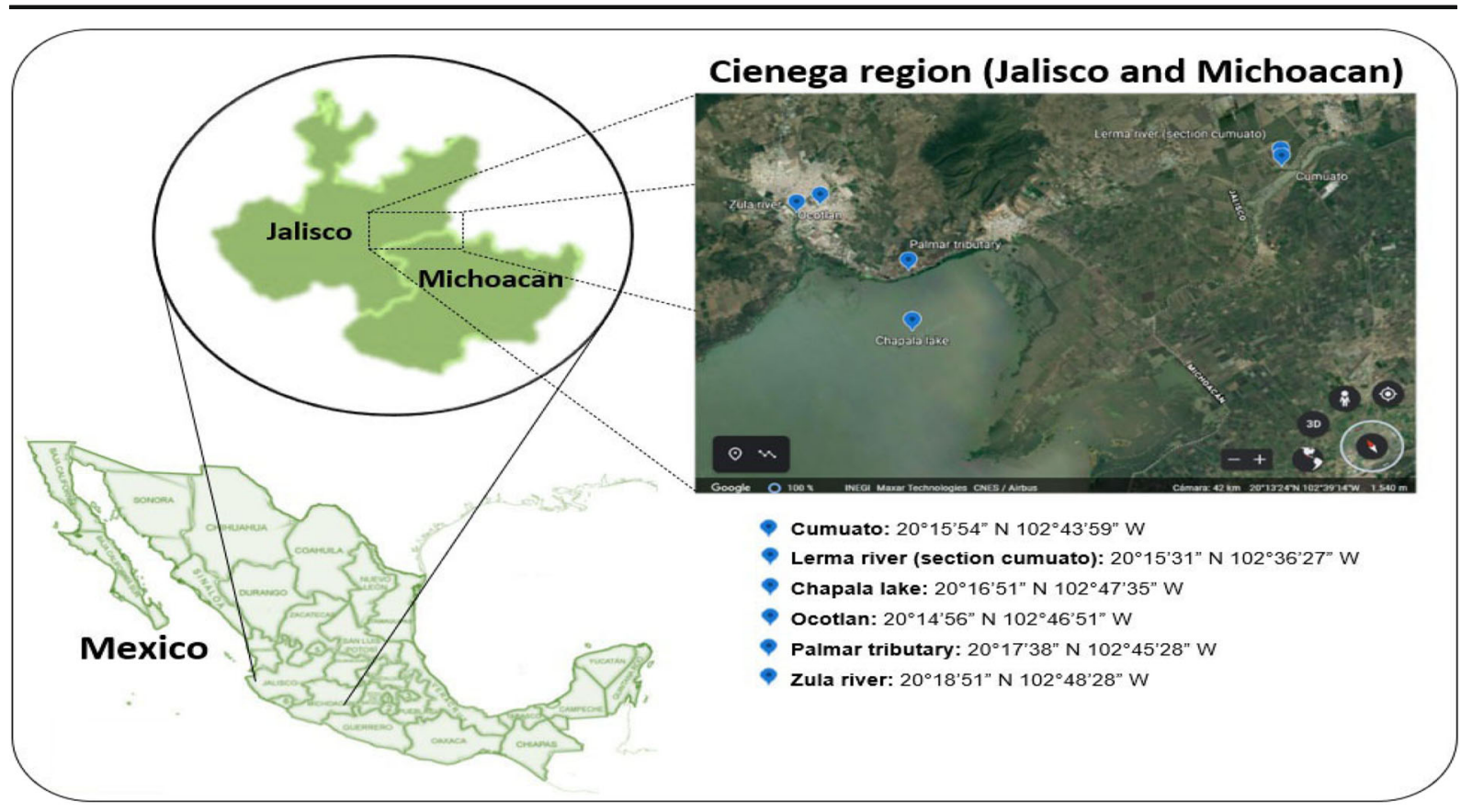

Fig. 1 Sampling sites in the Cienega region, located between the states of Jalisco and Michoacan, Mexico (indicated by blue dots). Image taken from Google Earth

$350{ }^{\circ} \mathrm{C}$, gas flow rate of $12 \mathrm{~L} / \mathrm{min}$, nebulizer pressure of 25 psi nebulizer, +4000 capillary in precursor ion and -4000 capillary in product ion. The time used to perform chromatographic analysis was $200 \mathrm{~ms}$ using multiple reaction monitoring (MRM) (Rodríguez-Aguilar et al. 2019). The mass spectrometry conditions for the determination of each pesticide are shown in Table 1. The validation of the method was performed according to Analytical Method Validation Guide Edited by The National College of Pharmaceutical Chemists Biologists Mexico, A.C. The analytical parameters evaluated were recovery (as a measure of accuracy), linearity, precision, limit of quantification, and limit of detection (Método Analíticos 2002).

\subsection{Analysis}

The results were analyzed with SPSS v19.0 software and are expressed as mean and standard deviation (SD). The data were compared using Student's $t$ test for samples matched with normal distribution, while MannWhitney $U$ test was used for samples that did not meet a normal distribution. Multidimensional scaling (MSD) was carried out to group the zones on the basis of similarity in the concentrations of pesticides. A value of $p \leq 0.05$ was taken as indicative of statistical significance.

\section{Results}

The survey carried out on farmers revealed that the most frequently used pesticides were bipyridyls (31.95\%), followed by organophosphates $(28.87 \%)$, while the least used were pyrethroids (12.89\%). The frequencies of use of pesticides in the three groups are shown in Table 2. Within the organophosphates, glyphosate was the most frequently used pesticide $(14.43 \%)$, while alphacypermethrin was the most frequently used pyrethroid pesticide. Paraquat $(31.95 \&)$ was the most popular bipyridyl amongst the farmers.

Since glyphosate and malathion stood out amongst the 22 pesticides analyzed in water samples, subsequent studies were focused on these two pesticides. The remaining 20 pesticides were detected only in some samples at concentrations below $10 \mathrm{ppb}$. It is worth noting that picloram was the only pesticide that was present at concentrations higher than $10 \mathrm{ppb}$ and up to $100 \mathrm{ppb}$ in the samples of the Lerma river section Cumuato. In contrast, glyphosate and malathion were present at 
Table 1 Mass spectrometry conditions and characteristics of pesticides analyzed

\begin{tabular}{|c|c|c|c|c|}
\hline Compound & Precursor ion $(\mathrm{m} / \mathrm{z})$ & Product ion $(\mathrm{m} / \mathrm{z})$ & Fragment (v) & Polarity \\
\hline Parathion & 292 & 264 & 90 & Positive \\
\hline Parathion & 292 & 236 & 90 & Positive \\
\hline Picloram & 240.9 & 222.9 & 90 & Positive \\
\hline Picloram & 240.9 & 194.9 & 90 & Positive \\
\hline Ametrine & 228.1 & 186 & 120 & Positive \\
\hline Ametrine & 228.1 & 96 & 120 & Positive \\
\hline $2,4-\mathrm{D}$ & 219 & 161.1 & 50 & Negative \\
\hline Pyraclostrobin & 388 & 163 & 120 & Positive \\
\hline Malathion & 331 & 99 & 80 & Positive \\
\hline Diazinon & 305 & 153 & 160 & Positive \\
\hline Imazalil & 297 & 159 & 160 & Positive \\
\hline Dimethoate & 230 & 171 & 80 & Positive \\
\hline Carbofuran & 222 & 123 & 120 & Positive \\
\hline Atrazine & 216 & 132 & 120 & Positive \\
\hline Thiabendazole & 202 & 131 & 120 & Positive \\
\hline Molinate & 188.1 & 55.1 & 78 & Positive \\
\hline Acetochlor & 270.1 & 224.2 & 60 & Positive \\
\hline Acetochlor & 270.1 & 148.4 & 60 & Positive \\
\hline Carbendazin & 192.1 & 160 & 110 & Positive \\
\hline Emamectin & 887.1 & 158.1 & 60 & Positive \\
\hline Cialotrine & 467.1 & 225.1 & 80 & Positive \\
\hline Meclizine & 391.2 & 201.1 & 90 & Positive \\
\hline Methomyl & 163.1 & 106 & 30 & Positive \\
\hline Methomyl & 163.1 & 88.1 & 30 & Positive \\
\hline Metoxuros & 229.1 & 72.1 & 93 & Positive \\
\hline Oxandrolone & 325 & 289.2 & 100 & Positive \\
\hline Oxandrolone & 307.2 & 271.2 & 100 & Positive \\
\hline Oxandrolone & 307.2 & 229.1 & 100 & Positive \\
\hline Glyphosate & 168 & 149.9 & 80 & Negative \\
\hline Glyphosate & 168 & 124.2 & 80 & Negative \\
\hline
\end{tabular}

concentrations greater than $100 \mathrm{ppb}$. These results are presented in Table 3 and Fig. 2.

Table 3 shows high concentrations of malathion, especially for purifiers (863.49 ppb) and the community of Cumuato (848.11 ppb), and in other sampling zones. Compared to malathion, the levels of glyphosate were much lower. The highest concentration of glyphosate (510.46 ppb) was obtained in the community of Cumuato Lake Chapala, while lower and comparable levels of this pesticide were recorded in Zula River, tributary Palmar, and Lerma river section Cumuato. In contrast, low level of glyphosate (56.96 ppb) was seen in the community of Ocotlán in purifiers and in the University Center.

As shown in Fig. 2, for the seven sampling points studied, malathion concentrations were significantly and consistently higher than those of glyphosate levels.

\subsection{Glyphosate and Malathion Concentrations Between Sampling Areas}

Based on Mann-Whitney $U$ test, comparison of glyphosate concentrations amongst sampling areas was 


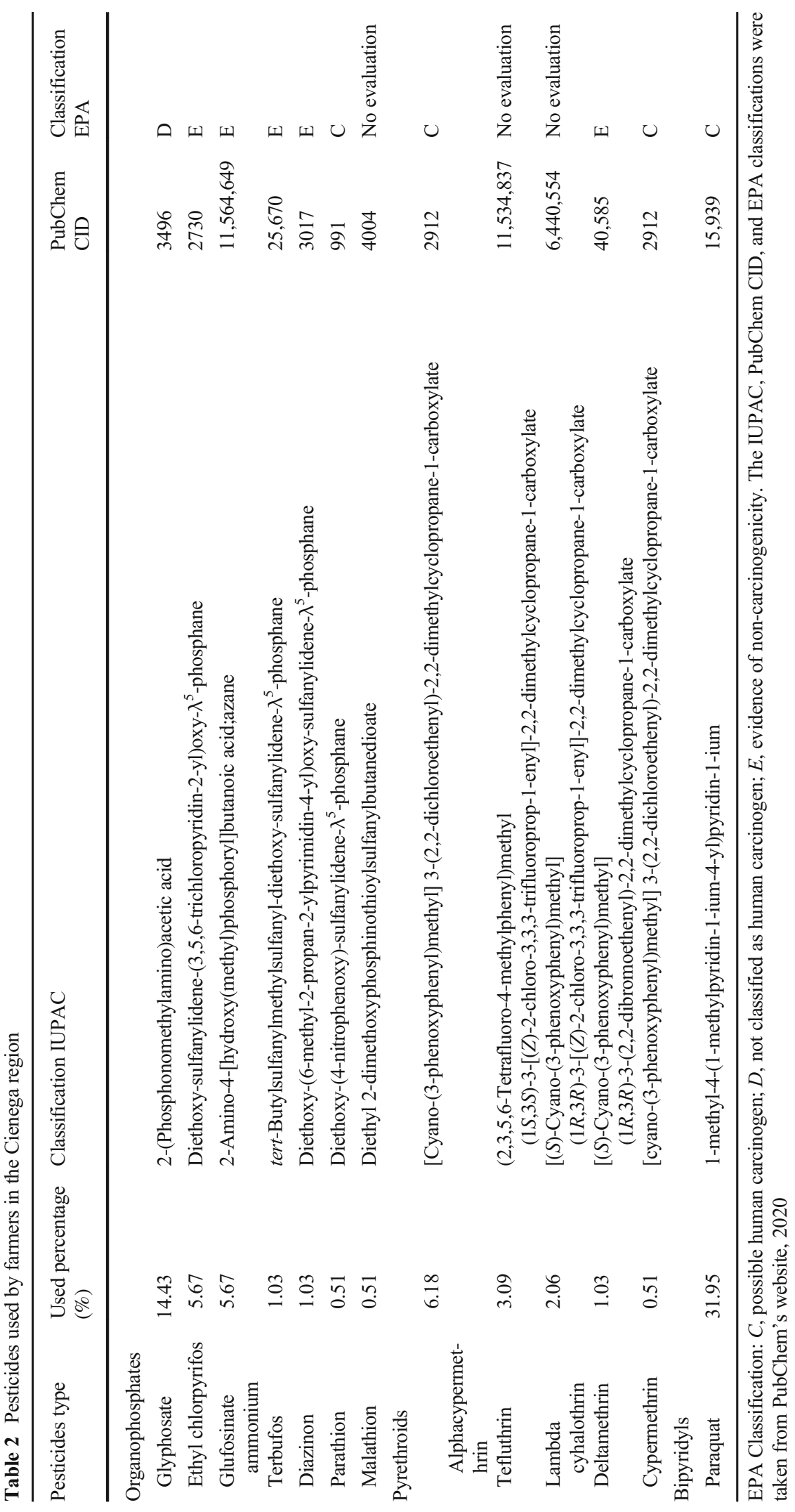


Table 3 Average value of glyphosate and malathion concentrations by sampling area

\begin{tabular}{|c|c|c|c|c|}
\hline Sampling area & $\begin{array}{l}\text { Mean } \\
\text { concentration } \\
\text { of malathion } \\
(\mathrm{ppb})\end{array}$ & SD & $\begin{array}{l}\text { Mean } \\
\text { concentration } \\
\text { of glyphosate } \\
(\mathrm{ppb})\end{array}$ & SD \\
\hline Chapala lake $(n=5)$ & 671.97 & 83.88 & 258.28 & 41.91 \\
\hline Zula river $(n=5)$ & 713.28 & 108.01 & 250.66 & 66.86 \\
\hline Palmar tributary $(n=5)$ & 717.34 & 66.03 & 228.53 & 37.29 \\
\hline Lerma river, section Cumuato $(n=12)$ & 311.76 & 84.67 & 252.17 & 78.70 \\
\hline Community of Cumuato $(n=5)$ & 848.11 & 53.78 & 510.46 & 442.51 \\
\hline Community of Ocotlan, Purifier $(n=11)$ & 863.49 & 111.41 & LOD* & LOD* \\
\hline Community of Ocotlan, Cuci $(n=8)$ & 771.498 & 91.08 & 56.96 & 59.73 \\
\hline
\end{tabular}

*Compound with concentration below the limit of detection. $S D$, standard deviation

performed. The results showed statistically significant differences between the community of Cumuato and the area of Cuci $(p \leq 0.05)$. A similar result was also seen with analysis using MDS (Fig. 3a), where a homogeneous distribution was distinguished in two dimensions. The first zone of similarity comprised the lake of Chapala, the river Zula, and the tributary of Palmar, while the second similar covered Lerma river section Cumuato, the community of Cumuato, and Cuci (stress $=0.005)$.

Malathion concentrations were also compared amongst sampling zones using the Mann-Whitney $U$ test. There were statistically significant differences in most of the paired comparisons $(p \leq 0.05)$. Moreover, MDS analysis showed a heterogeneous distribution amongst these areas (stress $=0.001$; Fig. $3 b$ ).
3.2 Glyphosate and Malathion Concentrations in Water Purification Plant Samples from Ocotlan

Samples for human consumption from 11 water purification plants show high concentrations of malathion (above $600 \mathrm{ppb}$, Table 4) and glyphosate values in a range above $10 \mathrm{ppb}$ and below $100 \mathrm{ppb}$ for 10 samples, except in the water purification plant 9 with a value of $120.1 \mathrm{ppb}$ (Table 4). The levels of malation of our results exceed the limits indicated by EPA in drinking water in urban public establishments (100 ppb for children and $200 \mathrm{ppb}$ for adults). With regard to glyphosate concentrations, they are within the permissible limits according to the World Health Organization (WHO). On the other hand, local and municipal government regulations monitor water

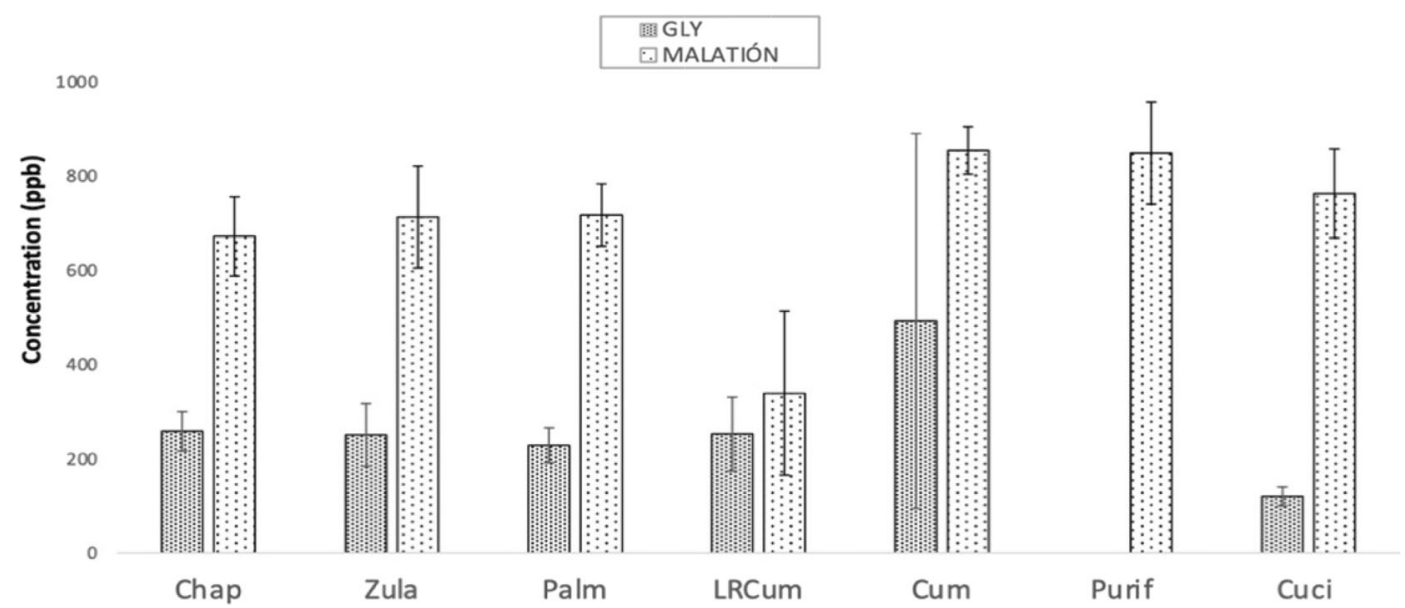

Fig. 2 Comparison of glyphosate and malathion concentrations ( $\mathrm{ppb}$ ) in 51 water samples from 7 different regions of the Cienega zone, Jalisco, Mexico 

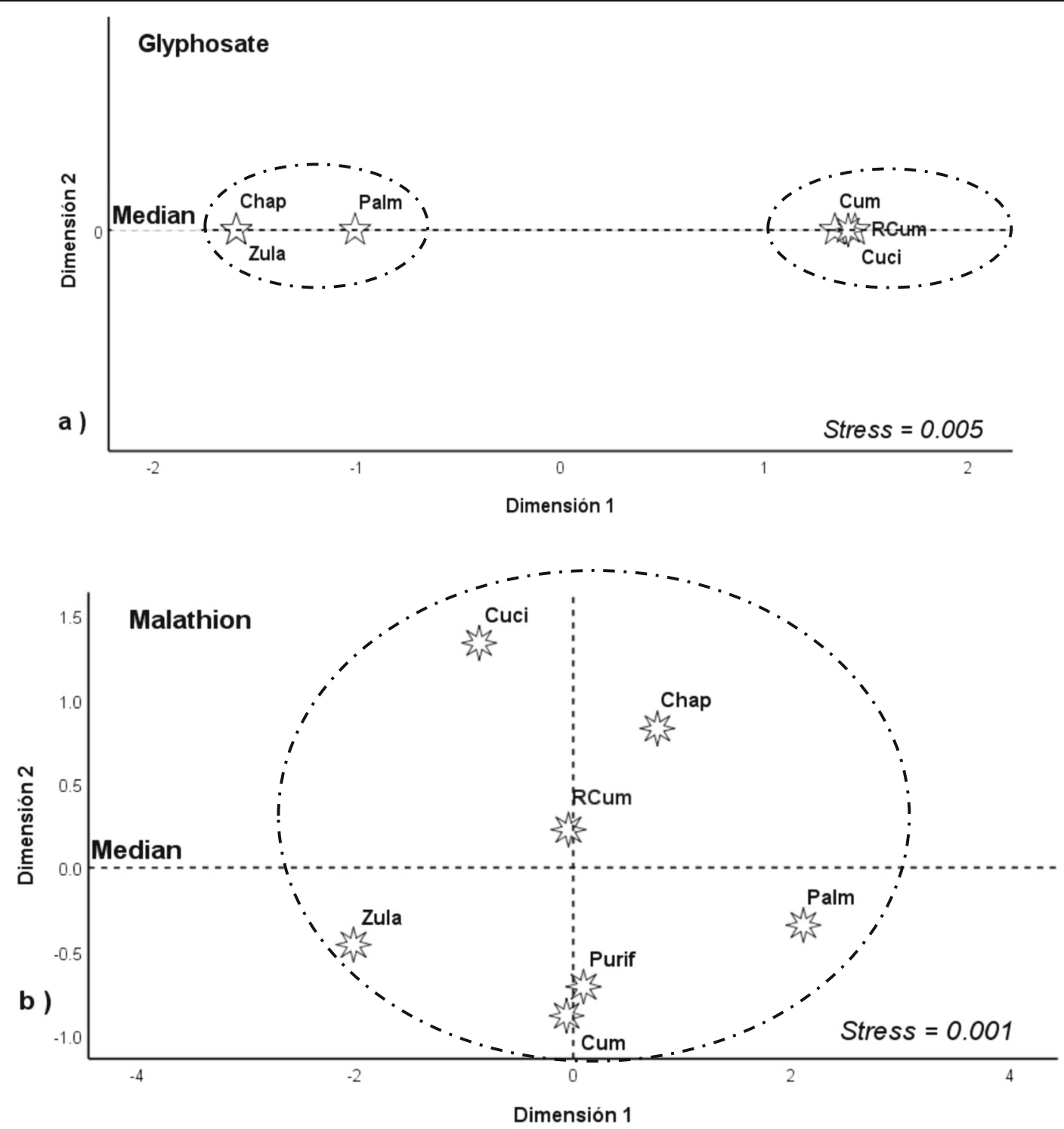

Fig. 3 a A multi-dimensional scaling (MDS) for the concentrations of glyphosate in different areas of the Cienega region; b MDS for the concentrations of malathion in the same areas in region

quality with respect to the concentration of organochlorine pesticides (NOMX-AA-071-1981, water analysis-determination of organochlorine pesticides), but not for organophosphates, it is therefore necessary to update an Official Mexican Standard that regulates the permissible limits of these pesticides.

\section{Discussion}

The Cienega region Jalisco is important at national level for its contributions to the production of wheat
$(68.05 \%)$, sorghum $(48.05 \%)$, corn $(27.75 \%)$, agave (4.8\%), and red tomato (4.0\%) (Transparencia 2004). It has been reported that the most frequently applied pesticides in agricultural fields in Jalisco, Mexico (Ayuquila-Armería river basin in Autlán de Navarro) are glyphosate, glufosinate, diazinon, parathion, malation, cypermethrin, lambda cialotrina, and paraquat (Pérez-Herrera et al. 2018; Rodríguez-Aguilar et al. 2019; Guzmán-Plazola et al. 2016). In this study, results from the Cienega region are consistent with the high frequencies of application of glyphosate, glufosinate, cypermethrin, and paraquat, with a $60.49 \%$ prevalence in the use of 
Table 4 Pesticide concentrations in 11 water purification plants in Ocotlan, Jalisco, Mexico

\begin{tabular}{|c|c|c|c|c|c|c|c|c|c|c|c|}
\hline \multirow[t]{2}{*}{ Pesticide (ppb) } & \multicolumn{11}{|c|}{ Water purification plants } \\
\hline & 1 & 2 & 3 & 4 & 5 & 6 & 7 & 8 & 9 & 10 & 11 \\
\hline Acetochlor & LOD & LOD & LOD & LOD & LOD & LOD & LOD & LOD & LOD & LOD & LOD \\
\hline Ametrin & LOD & LOD & LOD & LOD & LOD & LOD & LOD & LOD & LOD & LOD & LOD \\
\hline Atrazine & LOD & LOD & LOD & LOD & LOD & LOD & LOD & LOD & LOD & LOD & LOD \\
\hline Carbendazim & LOD & LOD & LOD & LOD & LOD & LOD & LOD & LOD & LOD & LOD & LOD \\
\hline Carbofuran & LOD & LOD & LOD & LOD & LOD & LOD & LOD & LOD & LOD & LOD & LOD \\
\hline Diazinon & LOD & LOD & LOD & LOD & LOD & LOD & LOD & LOD & LOD & LOD & LOD \\
\hline Dimethoate & LOD & LOD & LOD & LOD & LOD & LOD & LOD & LOD & LOD & LOD & LOD \\
\hline Emamectin & LOD & LOD & LOD & LOD & LOD & LOD & LOD & LOD & LOD & LOD & LOD \\
\hline Imazalil & LOD & LOD & LOD & LOD & LOD & LOD & LOD & LOD & LOD & LOD & LOD \\
\hline Cyhalothrin & LOD & LOD & LOD & LOD & LOD & LOD & LOD & LOD & LOD & LOD & LOD \\
\hline Malathion & 811.6 & 732.2 & 880.2 & 1051.2 & 784.7 & 901.2 & 903.8 & 747 & 857.4 & 1056.9 & 665.1 \\
\hline Meclizine & LOD & LOD & LOD & LOD & LOD & LOD & LOD & LOD & LOD & LOD & LOD \\
\hline Methomyl & LOD & LOD & LOD & LOD & LOD & LOD & LOD & LOD & LOD & LOD & LOD \\
\hline Metoxuros & LOD & LOD & LOD & LOD & LOD & LOD & LOD & LOD & LOD & LOD & LOD \\
\hline Molinate & LOD & LOD & LOD & LOD & LOD & LOD & LOD & LOD & LOD & LOD & LOD \\
\hline Oxandrolone & LOD & LOD & LOD & LOD & LOD & LOD & LOD & LOD & LOD & LOD & LOD \\
\hline Parathion & LOD & LOD & LOD & LOD & LOD & LOD & LOD & LOD & LOD & LOD & LOD \\
\hline Picloram & LOD & LOD & LOD & LOD & LOD & LOD & LOD & LOD & LOD & LOD & LOD \\
\hline Pyraclostrobin & LOD & LOD & LOD & LOD & LOD & LOD & LOD & LOD & LOD & LOD & LOD \\
\hline Thiabendazole & LOD & LOD & LOD & LOD & LOD & LOD & LOD & LOD & LOD & LOD & LOD \\
\hline Glyphosate & $<100$ & $<100$ & $<100$ & $<100$ & $<100$ & $<100$ & $<100$ & $<100$ & 120.1 & $<100$ & $<100$ \\
\hline $2,4-\mathrm{D}$ & LOD & LOD & LOD & LOD & LOD & LOD & LOD & LOD & LOD & LOD & LOD \\
\hline
\end{tabular}

herbicides, followed by fungicides with $39.05 \%$, and insecticides with a $20.92 \%$ (Sierra-Diaz et al. 2019).

\subsection{Pesticides with Concentrations Below $10 \mathrm{ppb}$}

Acetochlor, ametrine, atrazine, carbendazin, carbofuran, diazinon, dimethoate, emamectin, imazalil, cialotrin, meclizine, methomyl, methxurs, molinate, oxandrolone, parathion, pyraclostrobin, thiabendazole, and 2, 4 D had concentrations less than $10 \mathrm{ppb}$. This may be associated with multiple factors and is complex to elucidate, so we propose to carry out individual studies for each pesticide in the region.

\subsection{Concentrations of Glyphosate}

Glyphosate is not susceptible to photochemical degradation, and it has low mobility in aquatic sediments, with half-life in soil varying from months to years depending on environmental conditions (Vereecken
2005). The interaction of glyphosate with clay, iron oxide, phosphates, and organic matter (characteristics of the soil in the Cienega region) facilitates the formation of colloids, thereby reducing its adsorption in the soil and decreasing its concentration in groundwater (IIEG 2018; Vereecken 2005; Saunders and Pezeshki 2015; OMS 2004). Increased colloid formation decreases the microbial degradation of glyphosate (Vereecken 2005). A study has reported that $88.1 \%$ of applied glyphosate is retained in the surface layer of the soil and is dragged by runoff (Lupi et al. 2019). These factors, as well as high frequency of application of the herbicide in the region (14.43\%), are responsible for the high concentrations of glyphosate in the lake of Chapala, river Zula, tributary Palmar, Lerma river section Cumuato, and its community (228.53-510.46 ppb). The community of Cumuato had the highest concentration of glyphosate (442.51-510.46 ppb). Cumuato town is known for increases in the annual application of glyphosate. For example, glyphosate use increased from 
$408.1 \mathrm{~g} / \mathrm{ha}$ in the year 2012 to $2 \mathrm{~kg} / \mathrm{ha}$ in 2014 (BautistaÁvalos et al. 2014).

The MDS analysis showed similarity in glyphosate contamination for two statistically significant groups (stress $=0.005$ ): Group 1 covered the areas of Lerma river section Cumuato, the community of Cumuato, and Cuci. The homogeneity of the river and the Cumuato community were similar since they are dependent areas. However, the distance from Cumuato to Cuci is $35.1 \mathrm{~km}$. Thus, the homogeneity in MDS may be related to the high concentration of glyphosate in the water samples analyzed from Cuci (99.3-119.43 ppb). The surface tributaries of the University Center come from direct runoff from agricultural fields subjected to continuous application of pesticides. Group 2 covered the sampling points of Chapala Lake, Zula River, and tributary Palmar. The glyphosate concentrations for these 3 regions were similar, ranging from 228.53 to $258.28 \mathrm{ppb}$. This homogeneity of concentration is as a result of their interdependence on water exchange from Chapala Lake to the tributary of Palmar and the Zula River to Chapala Lake.

Regarding the levels of glyphosate in runoffs, surface water, and streams, in previous studies, variable concentrations of this herbicide ranging from 0.01 to $700 \mathrm{ppb}$ were reported. The highest concentrations of glyphosate were obtained from runoff basins near agricultural areas (Rodríguez-Aguilar et al. 2019; Coupe et al. 2012; Shipitalo and Owens 2011; Battaglin et al. 2005; Kjær et al. 2005 and Edwards et al. 1980). This is agreement with the results obtained in Cumuato, Cuci, and Lake Chapala.

\subsection{Concentrations of Malathion}

Malathion is a broad-spectrum organophosphate used in agriculture and also in public health for the control of vector transmission of insects (Singh et al. 2014). It has a moderate water solubility of $145 \mathrm{mg} / \mathrm{L}$ at $25{ }^{\circ} \mathrm{C}$ (OMS 2004). However, it is chemically degraded at temperatures of 27 to $32{ }^{\circ} \mathrm{C}$ from malathion to malathion monocarboxylic acid, malathion dicarboxylic acid and malaoxon. It is broken down at $\mathrm{pH}>7$ by bacterial enzymes such as organophosphate hydrolases, esterases, carboxylesterases, phosphatases and oxidoreductases, amongst others (Kumar et al. 2019). However, it has been confirmed that high concentrations of malathion saturate the enzyme active sites, thereby decreasing its decomposition (Kumar et al. 2019; Singh 2002). The photolytic half-life of malathion is 156 days under environmental conditions, but it decreases to 107 days under aqueous conditions (Kumar et al. 2019; Gao et al. 2018). The adsorption and mobility of malathion in the soil are almost zero, but they vary in response to degree of solid-liquid phase partition, soil $\mathrm{pH}$, organic matter content, and soil type (Al-Wabel et al. 2010). Sandy soil leads to the high adsorption of malathion (Kulluru et al. 2010). Once applied on crops, most of the malathion remains in the area of application, and due to its low absorption, rain, fog, or wind can mobilize the insecticide (OMS 2004). In the zone of Cienega, Jalisco, one of the most used insecticides for control of the population of mosquitoes is malathion in $44 \%$ emulsion with water (CENAVECE 2014). This explains why high concentrations of this insecticide were found in all sampling areas, despite its low use by farmers $(0.51 \%)$. In general terms, the concentration of malathion tripled that of glyphosate in the same samples, with the lowest concentration observed in Lerma river section Cumuato (311.76 \pm 84.67$)$.

It was observed that the results for malathion were high and variable. This variation may be due to periodic fumigations of malathion by the Ministry of Health in the Cienega area, which is also reflected in the dispersion of the MDS data. Over time, the application of malathion (manual and fumigation) allows the accumulation of this insecticide in tributaries, runoff, and streams. This is compounded by its poor adsorption in the clay type of soil in the zone Cienega, thereby contributing to its high levels in aqueous surfaces (Kulluru et al. 2010; IIEG 2018). Analysis of various reports in the literature on the concentrations of malathion in surface water and runoff shows that the highest levels in water were reported in the Ayuquila-Armería River in the states of Jalisco-Colima, Mexico (average: $500120 \mathrm{ppb}$ ), a value that is very close to that reported in drainage waters in Damietta, Egypt, with a range of 71.9 to $466 \mathrm{ppb}$ (Burgos-Hernández et al. 2006; Morales et al. 2019; Rodríguez-Aguilar et al. 2019; Abdel-Halim et al. 2006; Anderson et al. 2018; Sankararamakrishnan et al. 2005; Mekonen et al. 2016; Derbalah et al. 2019). In this study, the results obtained in the Cienega region are disturbing. 
4.4 Glyphosate and Malathion Levels in Water Purification Plants

In 2017, Mexico was ranked the third country in the world in bottled water consumption (Fortune 2019; IBWA 2017). About 7000 micro- and small companies participate in the market of water purification at national level (Pacheco-Vega 2015). The purification process of water treatment plants in Mexico is based on Official Mexican Standards NOM-230-SSA1-2002, NOM-014SSA1-1993, NOM-041-SSA1-1993, NOM-092-SSA11994, Nom-112-SSA1-1994, NOM-117-SSA1-1994, NOM-127-SSA1-1994, NOM-160-SSA1-19941995, and NOM-201-SSA1-2002. The water purification plants in Mexico use filtration techniques with sand beds and activated carbon filters to exclude particles of up to $30 \mu \mathrm{m}$, thereby eliminating residues of chlorine, dyes, and organic pollutants such as pesticides, herbicides, and hydrocarbons. Subsequently, the filtered water passes through a softener in order to remove hard minerals via ion exchange. The softened water is then directed to a multi-retention polishing filter that removes particles of sizes 25 $5 \mu \mathrm{m}$. Once the liquid is free of residues, it passes into a reverse osmosis chamber of one or more membranes to remove germs and reduce traces of salts and minerals, followed by exposure to ultraviolet light and an ozone generator, broad-spectrum germ neutralizer where up to $99.9 \%$ of microorganisms are eliminated (Vera 2008). There are few studies regarding the water quality of purifier plants. A study evaluated the risk points during the water purification process in establishments in Veracruz, Mexico, and identified weaknesses in the purification plants. These weaknesses were as follows: poor quality of the municipal water from which they are supplied, low frequency of physico-chemical analysis of the water, and poor maintenance of calibration filters and purification systems (Nexticapa et al. 2018). Moreover, there are reports of purifiers in Mexico with dubious quality of water processing which lead to public health risk (Mesa 2010).

High concentrations of malathion in $100 \%$ of the samples analyzed (665.1-1056.9 ppb) were obtained in water purification plants samples for human consumption. In contrast, much lower malathion concentrations were obtained in water for human consumption in Venezuela, ranging from 0.012 to $2.033 \mathrm{ppb}$ (Flores et al. 2011). The high levels of malathion found in bottler water consumption in the Cienega region may be related to the quality of water from which the treatment plants of these establishments get their supply. The water supply comes the tributaries of the Cienega area, i.e., lake of Chapala, river Zula, and tributary the Palmar; all of which had elevated levels of malathion. The concentrations of malathion reported in water purification plants were above the EPA-suggested limit (100 ppb for children and $200 \mathrm{ppb}$ for adults). Exposure to malathion, in particular its malaoxon metabolite and isomalathion, is associated with genetic damage in lymphocytes, increased risk of incidence to different carcinomas, damage to the hematopoietic system, diffuse parenchymal degeneration of hepatocytes (Tchounwou et al. 2015), and effects associated with neurotoxicity (Salama et al. 2015). Therefore, there is urgent need for close monitoring of water purification plant supply facilities in the Cienega region of Jalisco.

The levels of the herbicide of glyphosate were close to $150 \mathrm{ppb}$. This may be due to the high frequency of use of the herbicide within the Cienega region (14.43\%). Hepatic and renal glyphosate exposure has increased enzymatic activity of glutathione and glutathione peroxidase. In the central nervous system, glyphosate has a mechanism similar to glutamate agonist inducing neuronal death (Silva-Madera et al. 2019). On the other hand, glyphosate is associated with non-Hodgkin's lymphomas, renal tubule carcinoma, hemangiosarcoma, pancreatic islet adenomas, and breast cancer (SilvaMadera et al. 2019; Berry 2020).

It is important to emphasize that there is insufficient information in the literature about the quality of water purifiers, their processing, and the concentration of pesticides. Thus, this study is a pioneering effort in this type of analysis in the region and the country.

\subsection{Weaknesses of the Study}

Further studies should include the following: (a) assessment of the concentration of metabolites such as breakdown products of malathion and glyphosate; (b) determination of the concentrations of malathion and glyphosate in dry weight of filters in purifying plants to corroborate saturation with these pesticides; (c) increasing the number of samples and using consecutive sampling at different times of the year in both surface water and water for human consumption. 


\section{Conclusion}

Efficient techniques are now required for the detection and resolution of surface and drinking water quality problems in many countries. This study shows the potential use of HPLC MS/MS for pesticide detection in surface and drinking water samples in the Cienega region of Jalisco, Mexico. The results indicate that despite analyzing a total of 22 pesticides, only the concentrations of glyphosate and malathion were high. Glyphosate was present in most of the sampled sites, but only the community of Cumuato showed values higher than those consistent with the Daily Intake Acceptable in Water according to the WHO. However, this did not apply to urban public establishments sampled in the city of Ocotlán Jalisco. Malathion was also present in all the sampled sites, even in urban public establishments, at levels above the limits recommended by EPA. This may pose a public health risk. Multidimensional scaling analysis (MDS) showed that the sampled sites could be grouped into 2 different bodies of water, according to their homogeneity in glyphosate concentrations, while malathion had more heterogeneous concentrations. This is the first study to assess water quality in relation to pesticide contamination in the Cienega region. It is therefore hoped that these results will help federal and local authorities adopt new guidelines for assessing water quality so as to prevent drinking water shortages and water-borne diseases that endanger human health.

Acknowledgments We thank Karen Itzel Zúñiga Sánchez, María Fernanda Núñez Suárez, and Miguel Ángel Recendiz Núñez for their assistance in the field.

Authors' Contribution J. Salazar-Flores and E. D. TorresSánchez critically revised manuscript for important intellectual content. R. J. Silva-Madera, A. A. Peregrina-Lucano, and J. Mendoza-Michel contributed to acquisition and processing of data. H. R. Ceja-Gálvez, D. Rojas-Bravo, and M. Z. ReynaVillela contributed to analysis and preparation of data for published. H. R. Ceja-Galvez made the substantive translation. E. D. Torres-Sánchez, R. J. Silva-Madera, and J. Salazar-Flores contributed to conception of the study. Beside E. D. Torres-Sánchez and J. Salazar-Flores contributed to interpretation data and write original draft preparation. All the authors gave final approve and agree to be accountable for all aspects of the work in ensuring that question relating to the accuracy or integrity of any part of the work are appropriately investigated and resolved.
Funding This work was funded by the Program for the Improvement of Production Conditions of the SNI and SNCA Members (PRO-SNI 2019) RG/19/2019 of the University of Guadalajara, Jalisco, Mexico.Data AvailabilityThe data that support the findings of this study are available from the corresponding author, upon request.

\section{Compliance with Ethical Standards}

Competing Interests The authors declare that they have no conflicts of interest.

Open Access This article is licensed under a Creative Commons Attribution 4.0 International License, which permits use, sharing, adaptation, distribution and reproduction in any medium or format, as long as you give appropriate credit to the original author(s) and the source, provide a link to the Creative Commons licence, and indicate if changes were made. The images or other third party material in this article are included in the article's Creative Commons licence, unless indicated otherwise in a credit line to the material. If material is not included in the article's Creative Commons licence and your intended use is not permitted by statutory regulation or exceeds the permitted use, you will need to obtain permission directly from the copyright holder. To view a copy of this licence, visit http://creativecommons.org/licenses/by/4.0/.

\section{References}

Abdel-Halim, K. Y., Salama, A. K., El-Khateeb, E. N., \& Bakry, N. M. (2006). Organophosphorus pollutants (OPP) in aquatic environment at Damietta Governorate, Egypt: implications for monitoring and biomarker responses. Chemosphere, 63(9), 14911498. https://doi.org/10.1016/j.chemosphere.2005.09.019.

Al-Wabel, M. I., Abdel-Nasser, G., Al-Turki, A. M., \& El-Saeid, M. H. (2010). Behavior of atrazine and Malathion pesticides in soil: sorption and degradation processes. Journal of Applied Sciences (Faisalabad), 10(16), 1740-1747. https://doi.org/10.3923/jas.2010.1740.1747.

Anderson, B. S., Phillips, B. M., Voorhees, J. P., Deng, X., Geraci, J., Worcester, K., \& Tjeerdema, R. S. (2018). Changing patterns in water toxicity associated with current use pesticides in three California agriculture regions. Integrated Environmental Assessment and Management, 14(2), 270281. https://doi.org/10.1002/ieam.2005.

Arora, R., Chang, E., Li, G. Q., \& Raman, L. P. (2007). LC-MS-MS analysis of multi-residue pesticides in vegetables using liquidliquid extraction and pursuit@ XRs C18 HPLC columns. LC GC North America, 38-39. http://pascal-francis.inist.fr/vibad/index. php?action=getRecordDetail\&idt=18856227

Battaglin, W. A., Kolpin, D. W., Scribner, E. A., Kuivila, K. M., \& Sandstrom, M. W. (2005). Glyphosate, other herbicides, and transformation products in midwestern streams, 20021. JAWRA Journal of the American Water Resources 
Association, 41(2), 323-332. https://doi.org/10.1111/j.17521688.2005.tb03738.x.

Bautista-Ávalos, D., Cruz-Cárdenas, G., Moncayo-Estrada, R., García, J. T. S., \& Estrada-Godoy, F. (2014). Application of the SWAT model to evaluate the diffuse contamination sources at Lake Chapala sub-basin, Mexico. Revista Internacional De Contaminacion Ambiental, 263-274. http://www.scielo.org.mx/scielo.php?script=sci arttext\&pid=S0188-49992014000300003\&lng=es.

Berry, C. (2020). Glyphosate and cancer: the importance of the whole picture. Pest Management Science. https://doi. org/10.1002/ps.5834.

Burgos-Hernández, A., Zapién, M. G. L., Madrid, M. L. A., Sifuentes, C. O. G., Gil, C. I. M., Burgos, E. C. R., \& Olivas, R. R. (2006). Presence of insecticides in shrimp farms adjacent to the Sea of Cortes: detection, quantification, and toxicity testing. European Food Research and Technology, 222(3-4), 380-384. https://doi.org/10.1007/s00217-0050012-3.

Camps, S. P., \& Arroyo, M. G. (2018). Gobernanza ambiental en México y los impactos de la aplicación de los instrumentos de gestión ambiental: el caso de la cuenca alta del río Santiago. Expresión Económica. Revista de análisis, (41), 11. https://1 library.co/document/eqol1v7q-gobernanza-ambientalmexico-impactos-aplicacion-instrumentos-ambientalsantiago.html

CEA. (2020). Región 04 Cienega. Comisión Estatal del Agua, Jalisco. https://www.ceajalisco.gob. $\mathrm{mx} /$ contenido/municipios/regiones/reg04.php. Retrieved March 05, 2020.

CENAVECE. (2014). Centro Nacional DE Vigilancia Epidemiológica y Control de Enfermedades (CENAVECE). https://www.gob.mx/salud/acciones-y-programas/centronacional-de-vigilancia-epidemiologica-y-control-deenfermedades-cenavece. Retrieved March 10, 2020.

Coupe, R. H., Kalkhoff, S. J., Capel, P. D., \& Gregoire, C. (2012). Fate and transport of glyphosate and aminomethylphosphonic acid in surface waters of agricultural basins. Pest Management Science, 68(1), 16-30. https://doi.org/10.1002/ps.2212.

Derbalah, A., Chidya, R., Jadoon, W., \& Sakugawa, H. (2019). Temporal trends in organophosphorus pesticides use and concentrations in river water in Japan, and risk assessment. Journal of Environmental Sciences, 79, 135-152. https://doi. org/10.1016/j.jes.2018.11.019.

Edwards, W. M., Triplett Jr., G. B., \& Kramer, R. M. (1980). A watershed study of glyphosate transport in runoff. Journal of Environmental Quality, 9(4), 661-665. https://doi. org/10.2134/jeq1980.00472425000900040024x.

Flores, G. M. E., Molina Morales, Y., Balza Quintero, A., Benítez Díaz, R., \& Miranda Contreras, L. (2011). Residuos de plaguicidas en agua para consumo humano en una comunidad agrícola del estado de Mérida, Venezuela. Scielo, 52(4) http://ve.scielo.org/scielo.php?script=sci arttext\&pid=S0535-51332011000400002.

Fortune. (2019). Las ganancias millonarias del agua embotellada en México.https://www.fortuneenespanol. $\mathrm{com} /$ destacado/ganancias-millonarias-agua-embotelladamexico/. Retrieved March 11, 2020.

Gao, B., Chi, L., Tu, P., Bian, X., Thomas, J., Ru, H., \& Lu, K. (2018). The organophosphate malathion disturbs gut microbiome development and the quorum-sensing system. Toxicology Letters, 283, 52-57. https://doi.org/10.1016/j. toxlet.2017.10.023.

Guzmán-Plazola, P., Guevara-Gutiérrez, R. D., Olguín-López, J. L., \& Mancilla-Villa, O. R. (2016). Perspectiva campesina, intoxicaciones por plaguicidas y uso de agroquímicos. Idesia (Arica), 34(3), 69-80. https://doi.org/10.4067/S071834292016000300009.

Ibarrarán, M. E., Mendoza, A., Pastrana, C., \& Manzanilla, E. J. (2017). Determinantes socioeconómicos de la calidad del agua superficial en México. Región y sociedad, 29(69), 89125. https://doi.org/10.22198/rys.2017.69.a325.

IBWA. (2017). Bottler water. https://www.bottledwater.org. Retrieved March 11, 2020.

IIEG. (2018). Cienega, Diagnóstico de la Región, Jalisco. https://iieg.gob.mx/contenido/Municipios/04_cienega_ diagnostico.pdf. Retrieved March 09, 2020.

INAFED. (2020). Briseñas. Enciclopedoa de los Municipios y Delegaciones de México. http://www.inafed.gob. $\mathrm{mx} /$ work/enciclopedia/EMM16michoacan/municipios/16011 a.html. Retrieved March 05, 2020.

Kjær, J., Olsen, P., Barlebo, H. C., Henriksen, T., Juhler, R. K., Plauborg, F. L., ... \& Gudmundsson, L. (2005). The Danish Pesticide Leaching Assessment Programme. Monitoring results May 1999-June 2004. http://pesticidvarsling. dk/monitor_uk/2004.html. Retrieved March 10, 2020.

Kulluru, P. P., Das, B. S., \& Panda, R. K. (2010). Evaluation of sorption and leaching potential of malathion and atrazine in agricultural soils of India. International Journal of Environmental Research, 4(1), 75-90. https://doi. org/10.22059/IJER.2010.158.

Kumar, S. S., Ghosh, P., Malyan, S. K., Sharma, J., \& Kumar, V. (2019). A comprehensive review on enzymatic degradation of the organophosphate pesticide malathion in the environment. Journal of Environmental Science and Health, Part C, 37 (4), 288-329. https://doi.org/10.1080 $/ 10590501.2019 .1654809$.

Lupi, L., Bedmar, F., Puricelli, M., Marino, D., Aparicio, V. C., Wunderlin, D., \& Miglioranza, K. S. (2019). Glyphosate runoff and its occurrence in rainwater and subsurface soil in the nearby area of agricultural fields in Argentina. Chemosphere, 225, 906-914. https://doi.org/10.1016/j. chemosphere.2019.03.090.

Mekonen, S., Argaw, R., Simanesew, A., Houbraken, M., Senaeve, D., Ambelu, A., \& Spanoghe, P. (2016). Pesticide residues in drinking water and associated risk to consumers in Ethiopia. Chemosphere, 162, 252-260. https://doi. org/10.1016/j.chemosphere.2016.07.096.

Mesa, J. J. (2010). Estrategia de capacitación en análisis de riesgos, identificación y control de puntos críticos en 14 purificadoras de agua de la Jurisdicción Sanitaria de Orizaba, Veracruz. (Tesis Maestría). https://catalogoinsp.mx/cgi-bin/koha/opac-detail. pl?biblionumber $=11863 \&$ shelfbrowse itemnumber $=52802$. Retrieved March 09, 2020.

Método Analíticos, G. D. V. (2002). del Colegio Nacional de Químicos Farmacéuticos Biólogos. México: https://colegioqfb. org.mx/recurso/g/. Retrieved March 11, 2020.

Morales, D., Ponce, P., Cevallos, V., Espinosa, P., Vaca, D., \& Quezada, W. (2019). Resistance status of Aedes aegypti to deltamethrin, malathion, and temephos in Ecuador. Journal 
of the American Mosquito Control Association, 35(2), 113122. https://doi.org/10.2987/19-6831.1.

Nexticapa, R. M., Regules, E. A. M., Caballero R. D. A, Parra G. P. Y., Hernández V. P., Mateu, A. V., Garcimarrero E. E. A. (2018). Análisis de puntos de riesgo en purificadora de agua potable. Memoria presentada en XX Congreso Internacional de Inocuidad de Alimentos, Nuevo Vallarta, Nayarit, México. http://148.202.248.167/ojs/index. $\mathrm{php} /$ trabajosinocuidad/article/viewFile/389/231. Retrieved March 11, 2020.

OMS. (2004). Malathion in drinking-water. https://www.who. int/water_sanitation_health/dwq/chemicals/malathion. pdf?ua=1\#: : text=It $\% 20$ was $\% 20$ detected $\% 20 \mathrm{in} \% 204$ ,litre\%20(ATSDR\%2C\%202000). Retrieved March 10, 2020 .

Ortíz, I., Avila-Chávez, M. A., \& Torres, L. G. (2013). Plaguicidas en México: usos, riesgos y marco regulatorio. Revista Latinoamericana de Biotecnología Ambiental y Algal, 4(1), 1-21. https://doi.org/10.7603/s40682-014-0003-9.

Pacheco-Vega, R. (2015). Agua embotellada en México: de la privatización del suministro a la mercantilización de los recursos hídricos. Espiral (Guadalajara), 22(63), 221-263 http:/www.scielo.org.mx/scielo.php?script=sci_abstract\&pid= S1665-05652015000200007\&lng=es\&nrm=iso.

Pérez-Díaz, J. P., Ortega-Escobar, H. M., Ramírez-Ayala, C., Flores-Magdaleno, H., Sánchez-Bernal, E. I., Can-Chulim, Á., \& Mancilla-Villa, O. R. (2019). Concentración de nitrato, fosfato, boro y cloruro en el agua del río Lerma. Ecosistemas y recursos agropecuarios, 6(16), 175-182. https://doi. org/10.19136/era.a6n16.1829.

Pérez-Herrera, N., Vera-Avilés, M., Castillo-Burguete, T., PereraRios, J., Esperón-Hernández, R., Rojas-García, A. E., et al. (2018). Pesticide exposure index: practices among women from an agricultural community in southeast Mexico. Revista Internacional de Contaminación Ambiental, 34, 57-68. https://doi.org/10.20937/RICA.2018.34.esp02.05.

Rodríguez-Aguilar, B. A., Martínez-Rivera, L. M., PeregrinaLucano, A. A., Ortiz-Arrona, C. I., \& Cárdenas-Hernández, O. G. (2019). Análisis de residuos de plaguicidas en el agua superficial de la cuenca del Río Ayuquila-Armería, México. Terra Latinoamericana, 37(2), 151-161. https://doi. org/10.28940/terra.v37i2.462.

Salama, M., Lotfy, A., Fathy, K., Makar, M., El-emam, M., Elgamal, A., et al. (2015). Developmental neurotoxic effects of Malathion on 3D neurosphere system. Applied \& translational genomics, 7, 13-18. https://doi.org/10.1016/j.atg.2015.07.001.

Sanchez, H. U. R., García, M. E., Israde, I., \& Peña, Á. R. M. (2007). Disolución de sílice biogénica en sedimentos de lagos utilizados como bioindicadores de calidad del agua. $e$ Gnosis, 5 http://www.e-gnosis.udg.mx/index.php/egnosis/article/view/72.

Sankararamakrishnan, N., Sharma, A. K., \& Sanghi, R. (2005). Organochlorine and organophosphorous pesticide residues in ground water and surface waters of Kanpur, Uttar Pradesh, India. Environment International, 31(1), 113-120. https://doi.org/10.1016/j.envint.2004.08.001.

Saunders, L. E., \& Pezeshki, R. (2015). Glyphosate in runoff waters and in the root-zone: a review. Toxics, 3(4), 462480. https://doi.org/10.3390/toxics3040462.
Schaner, A., Konecny, J., Luckey, L., \& Hickes, H. (2007). Determination of chlorinated acid herbicides in vegetation and soil by liquid chromatography/electrospray-tandem mass spectrometry. Journal of AOAC International, 90(5), 14021410 PMID: 17955986.

Semarnat. (2020). La Semarnat impulsa procesos agroecológicos ante el uso excesivo de plaguicidas. Secretaría de Medio Ambiente y Recursos Naturales, México. https://www.gob. $\mathrm{mx} /$ semarnat/prensa/la-semarnat-impulsa-procesosagroecologicos-ante-el-uso-excesivo-de-plaguicidas. Retrieved March 06, 2020.

Shipitalo, M. J., \& Owens, L. B. (2011). Comparative losses of glyphosate and selected residual herbicides in surface runoff from conservation-tilled watersheds planted with corn or soybean. Journal of Environmental Quality, 40(4), 12811289. https://doi.org/10.2134/jeq2010.0454.

Sierra-Diaz, E., Celis-de la Rosa, A. D. J., Lozano-Kasten, F., Trasande, L., Peregrina-Lucano, A. A., Sandoval-Pinto, E., \& Gonzalez-Chavez, H. (2019). Urinary pesticide levels in children and adolescents residing in two agricultural communities in Mexico. International Journal of Environmental Research and Public Health, 16(4), 562. https://doi. org/10.3390/ijerph16040562.

Silva-Madera, R. J., et al. (2019). Glyphosate toxicity, oxidative stress, carcinogenicity and reproductive effects: a review. International Journal of Recent Scientific Research, 10(06), 32865-32869. https://doi.org/10.24327/ijrsr.2019.1006.3558.

Singh, D. K. (2002). Microbial degradation of insecticides: an assessment for its use in bioremediation. In Progress in Industrial Microbiology (Vol. 36, pp. 175-188). Elsevier. https://doi.org/10.1016/S0079-6352(02)80011-X.

Singh, B., Kaur, J., \& Singh, K. (2014). Microbial degradation of an organophosphate pesticide, malathion. Critical Reviews in Microbiology, 40(2), 146-154. https://doi.org/10.3109 /1040841x.2013.763222.

Tchounwou, P. B., Patlolla, A. K., Yedjou, C. G., \& Moore, P. D. (2015). Environmental exposure and health effects associated with Malathion toxicity. Toxicity and Hazard of Agrochemicals, 51, 2145-2149. https://doi.org/10.5772 /60911.

Transparencia. (2004). Plan Regional de Desarrollo, Región 04 Cienega, Jalisco. https://transparencia.info.jalisco.gob.mx/ sites/default/files/04.\%20Región\%2004\%20Cienega.pdf. Retrieved March 08, 2020.

Vera, C. O. (2008). Mejoramiento de la calidad de agua a través de un sistema integral de gestión en la planta purificadora de agua de luz ultravioleta. (Tesis de Maestría en Gestión de la Calidad). Universidad Veracruzana, México. Disponible en https://cdigital.uv.mx/bitstream/handle/123456789/47530 $/$ VeradelCallejoOscar.pdf? sequence $=1 \&$ isAllowed=y. Retrieved March 12, 2020.

Vereecken, H. (2005). Mobility and leaching of glyphosate: a review. Pest Management Science: formerly Pesticide Science, 61(12), 1139-1151. https://doi.org/10.1002 /ps.1122.

Publisher's Note Springer Nature remains neutral with regard to jurisdictional claims in published maps and institutional affiliations. 